\title{
First Report on Chemical Composition and Antimicrobial Activity of Artabotrys velutinus Scott-Elliot Extracts Against Some Clinical Strains in Benin
}

\author{
Mahudro Yovo", Guy Alain Alitonou, , , Hounnankpon Yedomonhan ${ }^{2}$, Fidele Tchobo ${ }^{1}$, \\ Oronce Dedome $^{1}$, Philippe Sessou ${ }^{1,3}$, Félicien Avlessi ${ }^{1}$, Chantal Menut ${ }^{4}$, Dominique Sohounhloué ${ }^{1}$ \\ ${ }^{1}$ Laboratory of Study and Research in Applied Chemistry (LERCA), Polytechnic School of Abomey-Calavi, University of Abomey-Calavi, \\ Abomey-Calavi, Republic of Benin \\ ${ }^{2}$ National Herbarium of Benin, University of Abomey-Calavi, Abomey-Calavi, Republic of Benin \\ ${ }^{3}$ Laboratory for Research in Applied Biology (LARBA), University of Abomey-Calavi, Abomey-Calavi, Republic of Benin \\ ${ }^{4}$ Institute of Biomolecules Max Mousseron, Team "Glyco and Nanocarriers for Therapeutic Targeting", Faculty of Pharmacy, Montpellier, \\ France
}

\section{Email address:}

alainguy20022002@yahoo.fr (G. A. Alitonou)

*Corresponding author

\section{To cite this article:}

Mahudro Yovo, Guy Alain Alitonou, Hounnankpon Yedomonhan, Fidele Tchobo, Oronce Dedome, Philippe Sessou, Félicien Avlessi, Chantal Menut, Dominique Sohounhloué. First Report on Chemical Composition and Antimicrobial Activity of Artabotrys velutinus Extracts Against Some Clinical Strains in Benin. American Journal of Applied Chemistry. Vol. 4, No. 3, 2016, pp. 71-76. doi: 10.11648/j.ajac.20160403.11

Received: March 24, 2016; Accepted: April 5, 2016; Published: April 27, 2016

\begin{abstract}
This work aims to study the chemical composition and to evaluate the antimicrobial activity, for the first time, of essential oil and non-volatile extracts of Artabotrys velutinus against Klebsiella pneumoniae 818E, Escherichia coli ATCC 25922 and Staphylococcus aureus ATCC 25933, three clinical strains of reference. The chemical analysis of essential oil of Artabotrys velutinus by GC and GC-MS showed that this oil rich in aromatic components $(62.6 \%)$ and sesquiterpene hydrocarbons (29.9\%) contains 30 compounds representing $98.9 \%$ of the oil. The major components of the essential oil were benzyl benzoate (61.2\%) also called ascabiol with and E- $\beta$-caryophyllene $(9.1 \%)$. The phytochemical screening of leaves powder of Artabotrys velutinus revealed the presence of saponins, catechin tannins, mucilages, flavonoids, alkaloid, anthocyanins, leuco-anthocyanins, reducing compounds, sterols and terpenes. The in vitro antibacterial activity of the extracts by agar diffusion method showed that only the ethanolic extract of the plant was more effective against $E$. coli with the highest inhibition zone of $13 \mathrm{~mm}$ at $100 \mathrm{mg} / \mathrm{mL}$ and Minimal Inhibitory Concentration equal to $50 \mathrm{mg} / \mathrm{mL}$. However, the activity of ethanolic extract of this plant was less active than those of reference antibiotics chloramphenicol and gentamycin which were very effective against the strains tested. In sum, essential oil of Artabotrys velutinus and its hydroethanolic extract present weakness antimicrobial activity contrary to its ethanolic extract which possesses moderate activity against clinical strains tested. This study suggests the used of ethanolic extract of Artabotrys velutinus in combination with others active extracts to fight against $E$. coli.
\end{abstract}

Keywords: Artabotrys velutinus, Essential Oil, Non-volatile Extract, Clinical Strains

\section{Introduction}

The genus Artabotrys was originally composed of 100 species of which 44 were described. Artabotrys velutinus Scott-Elliot, syn. Artabotrys djalonis A. Chev.; Artabotrys nigericus Hutch. (Annonaceae), is a useful plant of West
Tropical Africa (Guinee, Sierra Leone, Ghana and Nigeria) [1]. It's a climbing shrub or vine persistent, the nascent branches pubescent. Leaves up to $15 \mathrm{~cm}$ long and $6 \mathrm{~cm}$ broad, its outer petals linear or lanceolate are not sublets [2]. 
Artabotrys velutinus is used as an aphrodisiac. Traditionally, in tropical Africa and Benin in particular, people with low income, very often use plants collected locally for treatment of infections due pathogenic isolates such as Escherichia coli, Klebsiella pneumoniae and Staphylococcus aureus. Escherichia coli is responsible of affections manifested mainly by diarrhea whereas Staphylococcus aureus is mainly responsible of post-operative wound infections, endocarditis, osteomyelitis and food poisoning [3]. The most recent data of the International System of Monitoring of the Nosocomiales Infections arrange Klebsiella pneumoniae among the seventh most common agents implied in the nosocomiales infections of the urinary tract, infections of blood physiology, and the cardiovascular infections, the infections of the nose, the ears and the throat. It is also classified as fourth cause of acquired hospital pneumonias [4].

Only a very small number of species belonging to Artabotrys have so far been studied chemically. As far as we know, no investigations have been made on the chemical study and biological activity of the volatile oil obtained from Artabotrys velutinus. Therefore, as part of our continuous search for beneficial effects of plants extracts from Benin, we aimed to evaluate the antimicrobial activity of the essential oil hydrodistilled from leaves and ethanolic and hydroethanolic extrcats of Artabotrys velutinus after undertaken chemical investigation of these extracts in order to establish the composition-activity relationship.

\section{Materials and Methods}

\subsection{Plants Material}

Leaves of Artabotrys velutinus were collected in Bonou in the department of Oueme-Plateau in Benin. They were dried naturally on laboratory benches at room temperature until constant weight. Identification of the plant was made by Professor Akouègninou of National Herbarium of Benin in University of Abomey-Calavi where a voucher specimen was deposited under $\mathrm{N}^{\circ} \mathrm{AA} 6656 / \mathrm{HNB}$.

\subsection{Methods}

\subsubsection{Phytochemical Screening}

The plant extracts were screened for the presence of mucilages, alkaloids, flavonoids, steroids and terpenes, anthraquinones, tannins, saponins and heterosides based on the colouring and/or precipitation reactions of the chemical compounds contained in the plant following standards methods.

\section{i. Alkaloids}

Alkaloids were identified by Mayer's reagent and confirmed by Bouchardat test. Formation of cream or brown precipitate respectively indicated the presence of alkaloids [5].

ii. Flavonoids

A portion $(1 \mathrm{~g})$ of the extract was added to $1 \mathrm{~mL}$ of $10 \%$ $\mathrm{NaOH}$. Formation of a yellow coloration indicated the presence of flavonoids [6].

iii. Sterols and terpens
They have been demonstrated by Liebermann-Burchard test [7].

\section{iv. Saponins}

A portion (1g) of each extract was added to $5 \mathrm{~mL}$ of distilled water and vigorously shaken for $2 \mathrm{~min}$. Formation of froth indicated the presence of saponins [8].

\section{v. Tannins}

$10 \mathrm{~mL}$ of distilled water was added to $2 \mathrm{~g}$ of each extract, stirred and filtered. $1 \mathrm{~mL}$ of ferric chloride was then added to the filtrate. Formation of a blue-green precipitate indicated the presence of tannins [9].

vi. Leuco-anthocyanins

$0.5 \mathrm{~mL}$ of $12 \mathrm{~N} \mathrm{HCl}$ was poured into $3 \mathrm{~mL}$ of extract. The acidified solution was brought to boiling water bath for 30 minutes. After cooling, the appearance of a purplish red color indicated the presence of leuco-anthocyanins [10].

vii. Anthocyanins

To an infusion, $5 \mathrm{~mL}$ of $10 \% \mathrm{H}_{2} \mathrm{SO}_{4}$ and $5 \mathrm{ml}$ of $50 \%$ $\mathrm{NH}_{4} \mathrm{OH}$ were added. The appearance of a red color that turned purplish blue in basic medium indicates the presence of anthocyanins [11].

viii. Mucilages

$1 \mathrm{~mL}$ of decoction $10 \%$ of plant powder was introduced in a test tube and $5 \mathrm{ml}$ of ethyl ether were added. After ten minutes, a flocculent precipitate indicates the presence of mucilages [10].

\section{ix. Carotenoids and quinones}

Free anthraquinones and combined quinones (Oheteroside and C-heteroside) were characterized respectively by the reaction of Bornträger [12] and standard method reported by [13].

\subsubsection{Quantitative Analysis of Phenolic Compounds}

Total polyphenols: The method of determination of total polyphenols consisted to use a mixture of phosphotungstic and phosphomolybdic acid which was reduced during the oxidation of phenols in the mixture of tungsten blue oxide and molybden $[14,15]$. The absorbance was measured by a spectrophotometer (JENWAY 50/60 Hz) at $765 \mathrm{~nm}$. Gallic acid was used as reference and the total polyphenol content in the extract was expressed in mg of gallic acid equivalents per gram of dry matter.

Total flavonoids: The method of aluminum trichloride $\left(\mathrm{AlCl}_{3}\right)$ was used to quantify the total flavonoids. This technique was based on the formation of the aluminumflavonoids complex that had a maximum absorption at 500 $\mathrm{nm}[14,16]$.

\subsubsection{Extraction of the Essential Oil}

The dry leaves $(100 \mathrm{~g})$ of Artabotrys velutinus were separately ground and subjected to hydrodistillation with a Clevenger-type apparatus using $750 \mathrm{ml}$ of deionised water for $4 \mathrm{~h}$. The oil collected was dried over anhydrous sodium sulfate and stored at $-20^{\circ} \mathrm{C}$ until used.

\subsubsection{Chemical Analysis of Essential Oil \\ i. Gas chromatography \\ GC analyses were performed on a Varian gas}


chromatograph, model CP-3380, with a flame ionization detector equipped with a silica capillary column: HP5 J\&W Agilent (5\%-phenyl-methylpolysiloxane) $(30 \mathrm{~m} \mathrm{x} 0.25 \mathrm{~mm}$ i.d. $\mathrm{x} 0.25 \mu \mathrm{m}$ film); $\mathrm{N} 2$ was the carrier gas at $0.8 \mathrm{~mL} / \mathrm{min}$; injection of $1 \mu \mathrm{L} 1: 10 \mathrm{CH}_{2} \mathrm{Cl}_{2}$ solution, split ratio 1:100; injector temperature $220^{\circ} \mathrm{C}$, detector temperature $250^{\circ} \mathrm{C}$; temperature program $60-220^{\circ} \mathrm{C}$ at $3^{\circ} \mathrm{C} / \mathrm{min}$, then kept at $220^{\circ} \mathrm{C}$ during $20 \mathrm{~min}$. The linear retention indices of the components were determined relative to the retention times of a series of $n$-alkanes with linear interpolation. The percentage composition of the essential oil was computed by the normalization method from the GC/FID peak areas on the HP5 capillary column, response factors being taken as one for all compounds.

\section{ii. Gas chromatography-mass spectrometry}

GC/MS analyses were performed using a HewlettPackard GC 5890 series II equipped with a HP5 (5\%phenyl-methylpolysiloxane) fused silica column (30 m x $0.25 \mathrm{~mm}$; film thickness $0.25 \mu \mathrm{m}$ ) and a DB-Wax fused silica column ( $30 \mathrm{~m}$ x $0.25 \mathrm{~mm}$; film thickness $0.25 \mu \mathrm{m})$ interfaced with a quadrupole detector (Model 5972) applying the same temperature program as for the GC/FID analyses with the apolar column; the temperature program was $70^{\circ} \mathrm{C}$ for $2 \mathrm{~min}, 70-220^{\circ} \mathrm{C}$ at $5^{\circ} \mathrm{C} / \mathrm{min}$, then kept at $220^{\circ} \mathrm{C}$ during $38 \mathrm{~min}$ using the polar column (calculation of the linear retention indices on this column by coinjection with a series of n-alkanes); injector temperature, $220^{\circ} \mathrm{C}$; MS transfer line temperature, $250^{\circ} \mathrm{C}$; carrier gas, helium at a flow rate of $0.6 \mathrm{~mL} / \mathrm{min}$; injection type, split, $1: 10(1 \mu \mathrm{L}$ 10:100 $\mathrm{CH}_{2} \mathrm{Cl}_{2}$ solution); ionization voltage, $70 \mathrm{eV}$; electron multiplier $1460 \mathrm{eV}$; scan range 35-300 amu; scan rate, 2.96 scan/s. The identification of the constituents was based on comparison of their relative retention indices with either those of authentic samples or with published data in the literature [17] and by matching their mass spectra with those obtained with authentic samples and/or the NBS75K, Wiley $7^{\text {th }}$ NIST $98 \mathrm{EPA} / \mathrm{NIH}$, and FFNSC 2 libraries spectra.

\subsubsection{Ethanolic and Hydroethanolic Extracts Preparation}

$50 \mathrm{~g}$ of leaves powder of $A$. Velutinus were mixed with 500 $\mathrm{cm}^{3}$ of concerned solvent. Ethanol $96^{\circ}$ and ethanol-water $(50 / 50)$ were used respectively for ethanolic extract and hydroethanolic extract. The mixture of leaves powder and solvent was filtered and evaporated to dryness at $40^{\circ} \mathrm{C}$ using rotary evaporator. Each residue was then allowed to cool, weighed and stored in refrigerator until needed.

\subsubsection{Antibacterial Assay}

\section{i. Agar disc diffusion method}

The agar disc diffusion method described by National Committee for Clinical Laboratory Standards reported by [18] was performed to determine the antibacterial activities of hydroethanolic, ethanolic extracts and essential oil of A. velutinus against E. coli ATCC 25922, S. aureus 25923 and $K$. pneumoniae $818 \mathrm{E}$, three pathogenic clinical bacteria of reference provided by the Laboratory of BacteriologyParasitology of Centre National Hospitalo-Universitaire
(CNHU), the first and biggest hospital of Benin. The bacterial cultures were first grown on Nutrient agar plates at $37^{\circ} \mathrm{C}$ for 18 to $24 \mathrm{~h}$. One or several colonies of the respective bacteria were transferred into normal saline and adjusted to 0.5 McFarland turbidity standards. The inoculum of the respective bacteria were streaked into Muller Hinton agar plates using a sterile swab and were then dried at $37^{\circ} \mathrm{C}$ during $15 \mathrm{~min}$. Sterile filter discs having $6 \mathrm{~mm}$ of diameter soaked with $25 \mu \mathrm{L}$ of $100 \mathrm{mg} / \mathrm{mL}$ of each non-volatile extract, 5 and $10 \mu \mathrm{L}$ of pure essential oil extract separately were placed at the surface of Muller Hinton agar plates. The plates were incubated for $24 \mathrm{hrs}$ at $370^{\circ} \mathrm{C}$. The antibacterial activity was evaluated by measuring the clear zone surrounding the whatman paper. Standard discs of antibiotics (Gentamicin $10 \mu \mathrm{g}$ and Chloramphenicol $30 \mu \mathrm{g}$ ) were applied as positive antibacterial controls. Each assay was performed in triplicates $[12,19]$.

\section{ii. Minimal Inhibitory Concentration Determination}

The method used is that reported by [3] using the microplates with 96 wells and Muller Hinton Broth (MHB). A negative control made of a mixing of tested ethanolic extract and the medium MHB and a positive control carried out with a mixing of tested microorganism and the MHB without the extract standardize the method. Serial dilutions have been made well by well, beginning by the first well to the twelfth one; the remaining aliquot is rejected at the end. The cultured microplates are incubated at $37 \pm 1{ }^{\circ} \mathrm{C}$ for 24 hours, covered with a parafilm paper. For the reading, the wells corresponding to the smallest concentration of extract of essential oil for which we do not observe turbidity or visible growth to the naked eye is taken as the minimum inhibitory concentration (MIC) of the extract on the strain tested.

\subsubsection{Statistical Analysis}

All assays were conducted at least three times with three different sample preparations. All data were expressed as mean \pm standard deviation (SD). Analysis of variance was performed using In Stat (Graph Pad software, San Diego CA). A one-way ANOVA and unpaired Student's t-test were used for these analyses, and $\mathrm{p}<0.05$ was considered to be statistically significant.

\section{Results and Discussion}

\subsection{Chemical Composition of the Leaves Powder of Artabotrys Velutinus}

The table 1 presents the results of chemical characterization of the leaves of Artabotrys velutinus. Various secondary metabolites have been identified in the leaves by a series of color reactions and precipitation more or less specific to each class of active ingredients. Among these secondary metabolites we have saponins, catechin tannins, mucilages, flavonoids, alkaloid, anthocyanins, leuco-anthocyanins, reducing compounds, sterols and terpenes. 
Table 1. Main Metabolites of A. velutinus leaves powder.

\begin{tabular}{lll}
\hline \multicolumn{2}{l}{ Secondary metabolites } & A. velutinus \\
\hline Tannins & Cathechic & + \\
& Galliques & - \\
Flavonoids & & + \\
Anthocyans & & + \\
Leuco-anthocyans & & + \\
Sterols et terpenes & & + \\
Alkaloïds & & + \\
Mucilages & & + \\
Reducing compounds & & - \\
& o-heterosides & + \\
Combined & o-heterosides with reduced & - \\
anthraquinones & genines & \\
& c-heterosides & \\
\hline
\end{tabular}

-: absence; +: presence

\subsection{Phenolic Compounds Contents of Ethanolic and Hydroethanolic Extracts}

The contents of total polyphenols, flavonoïds and condensed tanins of semi and ethanolic extracts of the leaves Artabotrys velutinus expressed out of equivalent $\mathrm{mg}$ of gallic acid per gram (mgEAg/g) and out of equivalent $\mathrm{mg}$ of catechin per gram $(\mathrm{mgEC} / \mathrm{g})$ of dry matter $(\mathrm{MS})$ are indicated by the figure 1 . The total phenols contents of the ethanolic and semi extracts studied are respectively of (256.622 \pm 10.797$) \mathrm{mgEAG} / \mathrm{g}$ MS and $(340 \pm 7.932) \mathrm{mgEAG} / \mathrm{g}$ MS and then $(210.420 \pm 3.998) \mathrm{mgEC} / \mathrm{g}$ and $(284.733 \pm 7.425)$ $\mathrm{mgEC} / \mathrm{g}$ for the contents of total flavonoïds. Regarding the condensed tanins, the highest content is obtained with the semi-ethanolic extract $(135.813 \pm 1.973) \mathrm{mgEC} / \mathrm{g}$ followed by ethanolic extract $(108.604 \pm 3.617) \mathrm{mgEC} / \mathrm{g}$. These contents increase with the polarity of extraction solvent.

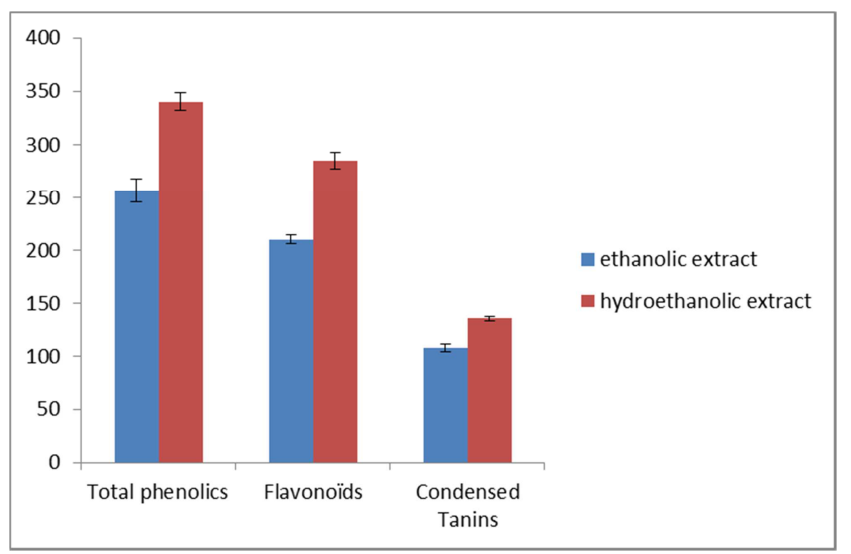

Figure 1. Phenolic compounds contents of volatile extracts studied.

\subsection{Chemical Composition of the Essential oil Hydrodistilled from Leaves of A. Velutinus}

The chemical composition of the essential oil obtained from the leaves of Artabotrys velutinus is reported in table 2. Results showed that the major fraction of the oil was aromatic compounds (62.6\%) followed by (29.9\%) of sesquiterpens hydrocarbons and oxygenated compounds (5.4\%). As shown by their proportions given in table 2 , the most abundant components in Artabotrys velutinus leaves essential oil are benzyl benzoate $(61.2 \%)$ also called ascabiol and $\mathrm{E}-(\beta)$-caryophyllene $9.1 \%$ while the minor components are $\alpha$-(E,E)-farnesene $(4.2 \%)$, caryophyllene oxide $(3.4 \%)$, germacrene-D $(2.6 \%), \alpha$-humulene $(2.5 \%)$, valencene (2.4\%), $\alpha$-copaene (1.9), methoxy benzyl benzoate (1.3\%), $\beta$ elemene (1.2\%), $\gamma$-amorphene $(1.2 \%), \alpha$-selinene $(1.0 \%)$ and bicyclogermacrene $(1.0 \%)$. The other minor compounds contents are less than $1.0 \%$ each one. An extensive review of literature on the biological activities of the major constituents of this oil shows that benzyl benzoate, the major compound has potent antiparasitic properties on mites including Sarcoptes scabei $[20,21,22,23,24]$ whereas (E)- $\beta$ caryophyllene, a sesquiterpene widely distributed in essential oils of various plants possesses several biological properties such as anti-inflammatory, antibiotic, antioxidant, anticarcinogenic and local anaesthetic activities [25]. In sum, essential of Artabotrys velutinus contains major chemical compounds which could allow it use as acaricidal agent.

Table 2. Chemical composition of the essential oil hydrodistilled from leaves of Artabotrys velutinus.

\begin{tabular}{|c|c|c|c|c|}
\hline $\mathbf{N}^{\circ}$ Pic & $\mathbf{R I}^{\mathrm{a}}$ & $\mathbf{R I}^{\mathrm{b}}$ & Components & $\%$ \\
\hline 1 & 844 & 1023 & (2E)-hexenal & 0.1 \\
\hline 2 & 937 & 1034 & $\alpha$-pinene & 0.1 \\
\hline 3 & 982 & 1139 & sabinene & 0.3 \\
\hline 4 & 1027 & 1243 & p-cymene & 0.3 \\
\hline 5 & 1384 & 1478 & $\alpha$-copaene & 1.9 \\
\hline 6 & 1394 & 1502 & $\beta$-bourbonene & 0.4 \\
\hline 7 & 1398 & 1580 & $\beta$-elemene & 1.2 \\
\hline 8 & 1431 & 1583 & (E)- $\beta$-caryophyllene & 9.1 \\
\hline 9 & 1441 & 1585 & $\beta$-copaene & 0.3 \\
\hline 10 & 1454 & 1589 & trans- $\alpha$-bergamotene & 0.3 \\
\hline 11 & 1465 & 1650 & $\alpha$-humulene & 2.5 \\
\hline 12 & 1472 & 1656 & allo-aromadendrene & 0.5 \\
\hline 13 & 1491 & 1659 & germacrene-D & 2.6 \\
\hline 14 & 1494 & 1662 & cis- $\beta$-guaiene & 0.2 \\
\hline $15 \mathrm{a}$ & 1498 & 1696 & $\gamma$-amorphene & 1.2 \\
\hline $15 b$ & 1498 & 1698 & valencene & 2.4 \\
\hline $16 \mathrm{a}$ & 1505 & 1702 & $\alpha$-selinene & 1.0 \\
\hline $16 b$ & 1505 & 1703 & bicyclogermacrene & 1.0 \\
\hline 17 & 1509 & 1730 & $\alpha$-(E,E)-farnesene & 4.2 \\
\hline 18 & 1530 & 1734 & $\delta$-cadinene & 0.7 \\
\hline 19 & 1563 & 1802 & germacrene B & 0.4 \\
\hline 20 & 1568 & 2006 & $\mathrm{M}=220$ & 0.3 \\
\hline 21 & 1577 & 2022 & (E)-nerolidol & 0.3 \\
\hline 22 & 1587 & 2100 & spathulenol & 0.8 \\
\hline 23 & 1594 & 2109 & caryophyllene oxide & 3.4 \\
\hline 24 & 1622 & 2171 & humulene epoxide II & 0.4 \\
\hline 26 & 1664 & 2198 & epi- $\alpha$-muurolol & 0.4 \\
\hline 27 & 1781 & 2610 & benzyl benzoate & 61.2 \\
\hline 28 & 2000 & 2616 & methoxy benzyl benzoate & 1.3 \\
\hline 30 & 2136 & 2642 & phytol & 0.1 \\
\hline \multicolumn{4}{|c|}{ Monoterpene hydrocarbons } & 0.7 \\
\hline \multicolumn{4}{|c|}{ Sesquiterpene hydrocarbons } & 29.9 \\
\hline \multicolumn{4}{|c|}{ Oxygenated sesquiterpenes } & 5.4 \\
\hline \multicolumn{4}{|c|}{ Aromatic compounds } & 62.6 \\
\hline \multicolumn{4}{|c|}{ Non identified } & 0.3 \\
\hline \multicolumn{4}{|c|}{ Total identified } & 98.9 \\
\hline
\end{tabular}

$\mathrm{RI}^{\mathrm{a}}$, Retention index relative to n-alkanes $\left(\mathrm{C}_{9}-\mathrm{C}_{20}\right)$ on a $\mathrm{DB}_{1}$ capillary column (5\%-phenyl-methylpolysiloxane);

$\mathrm{RI}^{\mathrm{b}}$, Retention index on Supelcowax 10 (polyethylene glycol); 


\subsection{Antibacterial Activity of Artabotrys Velutinus Extracts}

The results for antibacterial screening of extracts investigated are presented in Table 3 . The non-volatile extracts were tested at a concentration of $100 \mathrm{mg} \cdot \mathrm{mL}^{-1}$ in hydroethanolic solvent whereas 5 microliters and 10 microliters per disc of essential oil of the plant were tested. These results showed that only the ethanolic extract showed larger zones of inhibition against $E$. coli equal to $13 \mathrm{~mm}$. The Minimal Inhibitory Concentration determinated for ethanolic extract of this plant on $E$. coli was $50 \mathrm{mg} / \mathrm{mL}$. In contrast, the essential oil of this plant possessed weakness activity on Staphylococcus aureus with diameter of inhibition zone varying between 8 and $9 \mathrm{~mm}$. All the extracts investigated present a zero or a null activity on Klebsiella pneumoniae.
The oil as well as the hydroethanolic extract possessed a null activity on E. coli whereas the non-volatile extracts don't affect the growth of $S$. aureus strains. In contrast, the standards antibiotics used as reference such as Gentamycin and chloramphenicol to compare their activity with that of the extracts were very actives on all the strains with the pronounced activity demonstrated by the chloramphenicol. The effect of ethanolic extract on E. coli can be related to the phenols contained in this extract with synergic to other compounds associated that the hydroethanolic extract would not contain. Globally, the volatile extracts investigated as well as the essential oils are not active on the clinical strains studied. These extracts could be qualified of not suitable extracts for fighting against bacteria.

Table 3. Diameters ( $\mathrm{mm}$ ) of inhibition zone produced by the extracts on strains investigated.

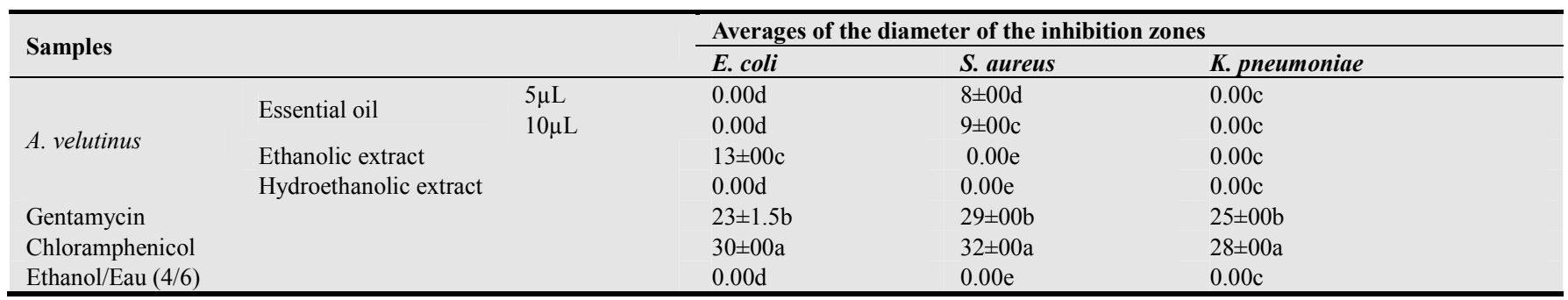

The values in column followed by different letters are significantly different at $\mathrm{p}<0.05$

\section{Conclusion}

In this study, the activity of two crude extracts and essential oil from the leaves of Artabotrys velutinus of Benin was evaluated in vitro against Klebsiella pneumoniae, Staphylococcus aureus and Escherichia coli. Of these extracts, only ethanolic extract exhibited moderate activity against $E$. coli. This is the first report of the activity of these plants which is rich in phenolic compounds, sesquiternes components and aromatic compounds such as benzyl benzoate with acaricidal activity. The oil of this plant could be useful for the fight against mites especially Sarcoptes scabei.

\section{Acknowledgments}

The authors are thankful to the Government of Benin for its financial support through the Scholarship fellowship initiated by the Ministry of Higher Education and Scientific Research.

\section{References}

[1] Bouquet, A., Debray, M. (1974). Medicinal plants of Ivory Coast. Works and file $\mathrm{N}^{\circ}$ : 32 ORSTOM Paris, France, 231p.

[2] Hutchinson, J., Dalziel J. M. (1954). Flora of West Tropical Africa, Vol I part I, $2^{\text {nd }}$ Edt, 294p.

[3] Yehouenou, B., Wotto, V., Bankole, H., Sessou, P., Noudogbessi, J. P., Sohounhloue, D. (2010). Chemical study and antimicrobial activities of volatile extracts from fresh leaves of Crassocephalum rubens (Juss \& Jack) s. Moore against food-borne pathogens. Scientific Study \& Research Chemistry \& Chemical Engineering, Biotechnology, Food Industry, 11(3), 343-351.

[4] Richards, M. J., Edwards R. J., Culver H. D., R. P. Gaynes, P. R. (1999). Nocosomial infections in medical intensive care units in the United States. Critical Care Medicine, 27, 887-892.

[5] Lebri, M., Bahi, C., Fofie, Y. B. N., Gnahoue, G, Lagou, M. S., Achibat, H., Yapi, A., Noel Zirihi, NG. (2015). Phytochemical analysis and acute toxicity evaluation by oral route in rats of total aqueous extract from leaves of Abrus precatorius Linn (Fabaceae). International Journal of Biological and Chemical Sciences, 9(3): 1470-1476.

[6] Coulibaly, A., Hafid, A., Khouili, M., Bruneton, J. (1999). Pharmacognosy, Phytochemistry, Medicinal Plants. Lavoisier Technique \& Documentation. Paris.

[7] Dohou, N., Yamni, K., Tahrouch, S., Idrissi Hassani, L. M., Badoc, A., Gmira, N. (2003). Phytochemical screening of endemic ibero-moroccan, Thymelaea lythroides. Bulletin de la Société de pharmacie de Bordeaux, 142, 61-78.

[8] Soro, T. Y., Traore, F., Datte, J. Y., Nene-Bi, A. S. (2009). Antipyretic activity of aqueous extract of Ximenia Americana. Phytoterapie, 7, 297-303.

[9] Bruneton, J. (1993). Pharmacognosy, phytochemistry, medicinal plants. $2^{\text {nd }}$ edition, Tec et Doc., Lavoisier, Paris, 915 p.

[10] Traore, F. (2010). Proposal formulation of an antimalarial syrup based argemon emexican papaveraceae. Médecine de Pharmacie et d'Odonto Stomatologie du Mali, 94 p. 
[11] Konan, K. M., Békro, M., Akhanovna, J., Békro, Y-A., Djié, B. M., Zomi, G., Bi Tra J. (2010). In vitro antioxidant activities of total flavonoids extracts from leaves and stems of Adenia lobata (Jacq.) Engl. (Passifloraceae). Journal of Pharmacognosy and Phytotherapy, 3, 8-12.

[12] Ponce, A. G., Fritz, R., del Valle C. E., Roura S. I. (2003). Antimicrobial activity of essential oils on the native microflora of organic Swiss chard. Lebensmittel-Wissenschaft und-Technologie-LWT, 36, 679-684.

[13] Agbangnan, C. P., Tachon, C., Bonin, C., Chrostowka, A., Fouquet, E., Sohounhloue, D. K. C. (2012). Phytochemical Study of a Tinctorial Plant of Benin Traditional Pharmacopoeia: The Red Sorghum (Sorghum caudatum) of Benin. Scientific Study \& Research, 13, 121-135.

[14] Singleton, V. I., Lamuela-Raventos, R. M. (2012). Analysis of Total Phenols and Other Oxidation Substrates and Antioxidants by Means of Folin-Ciocalteu Reagent. Method in Enzymology, 299, 15.

[15] Siddhuraju, P., Mohan, P. S., Becker, K. (2007) Studies on the antioxidant activity of Indian Laburnum (Cassia fistula L.), a preliminary assessment of crude extracts from stem bark, leaves, flowers and fruit pulp. Journal of Food Chemistry, 9, 61-67.

[16] Bahorun, T., Grinier, B., Trotin, T., Brunet, G., Pin, T., Lunck, M., Vasseur, J., Cazi, M., Cazin, C., Pinkas, M. (1996). Oxygen species scavenging activity of phenolic extracts from Hawthorn fresh plant organs and pharmaceutical preparations. Arzneimittel-Forsching, 46, 1086-1089.

[17] Adams, R. P. (2007). Identification of Essential Oils Components by Gas Chromatography/Mass Spectrometry, 4th Edition, Allured Publishing Corporation, USA.

[18] Mamadou, R. S., Moussa, I., Sessou, P., Yehouenou, B., Agbangnan, P., Illagouma, A., Abdoulaye, A., Sohounhloué, D., Ikhiri, K. (2014). Etude phytochimique, activités antiradicalaire, antibactérienne et antifongique d'extraits de Sebastiania chamaelea (L.) Müll. Arg. Journal de la Société Ouest Africaine de Chimie, 037: 10-17.

[19] Moreira M. R., Ponce A. G., de Valle C. E., Roura S. I. (2005). Inhibitory parameters of essential oils to reduce a foodborne pathogen. Lebensmittel-Wissenschaft und -Technologie-LWT, 38: $565-570$.

[20] Alberici, F., Pagani, L., Ratti, G., Viale, P. (2000). Ivermectin alone or in combination with benzyl benzoate in the treatment of human immunodeficiency virus-associated scabies. British Journal of Dermatology, 142(5), 969-972.

[21] Walton, S. F., Myerscough, M. R., Currie, B. J. (2000). Studies in vitro on the relative efficacy of current acaricides for Sarcoptes scabiei var. hominis. Transactions of the Royal Society of Tropical Medicine and Hygiene, 94 (1): 92-96.

[22] WHO (1999): Médicaments essentiels et produits de santé. http://apps.who.int/medicinedocs/fr/d/Jh2919f/27.html

[23] Monsel, G., Chosidow, O. (2015). Scabies, lice, and Myasis. In: Schlossberg, D (2015). Clinical Infectious Disease. Cambridge University Press, second Edition, ISBN: 978-1107-03891-2.

[24] Górkiewicz-Petkow, A. (2015). Scabicides and Pediculicides In: Andreas D. Katsambas, D. A., M. Lotti, M. T., Clio Dessinioti, C., Angelo Massimiliano D'Erme M.A. (2015). European Handbook of Dermatological Treatments, Springer Berlin Heidelberg doi 10.1007/978-3-662-45139-7_148, ISBN 978-3-662-45138-0, pp 1513-1518

[25] Legault, J., Pichette, A. (2007). Potentiating effect of $\beta$ caryophyllene on anticancer activity of $\alpha$-humulene, isocaryophyllene and paclitaxel. Journal of Pharmacy and Pharmacology, 59(12): 1643-1647. 